\title{
Corporate Carbon Disclosure, Financing Structure and Total Factor Productivity: Evidence from Chinese Heavy Polluting Listed Corporates
}

Sai Yuan ( $\nabla$ enduringpromise@163.com )

Dalian University of Technology https://orcid.org/0000-0003-1437-8349

\section{Xiongfeng Pan}

Dalian University of Technology

\section{Research Article}

Keywords: Carbon Disclosure, Financing Structure, Total Factor Productivity, Mediating Effect

Posted Date: December 1st, 2021

DOI: https://doi.org/10.21203/rs.3.rs-1087625/v1

License: (c) (1) This work is licensed under a Creative Commons Attribution 4.0 International License.

Read Full License 


\title{
Corporate Carbon Disclosure, Financing Structure and Total Factor Productivity: Evidence From Chinese Heavy Polluting Listed Corporates
}

\author{
Sai Yuan a,*, Xiongfeng Pan ${ }^{\mathrm{a}}$ \\ ${ }^{a}$ School of Economics and Management, Dalian University of Technology, Dalian 116024, China \\ Corresponding author: Sai Yuan; E-mail address: enduringpromise@163.com; +86 15689990531.
}

Abstract: Low-carbon economy has become the current global economic development trend, and Corporate carbon disclosure has attracted more and more attention from scholars and investors. This paper creatively explores the mechanism of corporate carbon disclosure quality on total factor productivity with financing structure as a mediating variable. The content analysis method is used to construct a carbon disclosure evaluation index system that is suitable for Chinese companies. Through the mediating effect model and Sobel test, the internal mechanism of carbon disclosure quality affecting total factor productivity is analyzed, with Chinese heavy polluting listed corporates from 2015 to 2018 as research samples. The empirical results show that, Firstly, the Quality of carbon disclosure has a positive effect on the improvement of total factor productivity. The effect of monetary carbon disclosure quality on the improvement of total factor productivity is higher than that of non-monetary carbon disclosure quality. Secondly, the financing structure has a mediating effect on the quality of carbon disclosure and total factor productivity, and the mediating effect of internal financing capabilities is better than those of external financing costs. Finally, external financing costs and internal financing capabilities 
have mediating effects in both heterogeneous carbon disclosure quality and total factor productivity. The mediating effect of internal financing capabilities is significantly higher than the mediating effect of external financing costs. Meanwhile, the effect of monetary carbon disclosure quality on total factor productivity indirectly through internal financing capabilities is higher than that of non-monetary carbon disclosure quality.

Keywords: Carbon Disclosure; Financing Structure; Total Factor Productivity; Mediating Effect

\section{Introduction}

As the phenomenon of global warming intensifies, the low-carbon economy has become an effective way to solve climate warming and is the consensus reached by most countries in addressing climate change issues (Clarkson et al, 2018). Although China is one of the largest carbon emitters in the world, it is also a participant in the construction of global ecological civilization (Zheng et al, 2019). In 2015, China promised at the Paris Climate Conference that China is expected to achieve the goal of reducing carbon emissions per unit of GDP by 60\%-65\% from 2005 around 2030 (Tollefson, 2016), and to start a national carbon trading market covering major industries in 2017. The market size of the carbon trading market has reached 4 billion tons of carbon equivalent, which is more than twice the size of the European carbon trading market, becoming the world's largest carbon trading system (Wen et al, 2020). As the cells of the national economy, enterprises are the main source of carbon emissions, but they are also the basic unit for implementing low-carbon development policies ( $\mathrm{Li}$ et al, 2018). The carbon emissions reduced by each enterprise's economic activities will become an important part of the overall carbon emissions reduction at the national level (Besio and Pronzini, 2014; Haney, 2017). The Chinese government attaches great importance to the carbon emissions of corporate economic activities. The Ministry of Ecology and Environment of China has issued the "Guidelines for Disclosure of Environmental 
Information for Listed Companies", which requires listed companies in 16 heavy-polluting industries, such as thermal power, steel, cement, and electrolytic aluminum, to publish annual environmental reports and regularly disclose pollutant emissions, environmental compliance, and environmental management (Luo et al, 2019). The objective and open disclosure of carbon information by enterprises have important reference value for establishing carbon trading markets and setting carbon emission reduction targets (Aragón-Correa et al. 2016). In recent years, many Chinese companies, especially heavily polluting industries, have disclosed information related to carbon emissions through the release of special social responsibility reports and corporate sustainability reports. However, corporate carbon disclosure is still mainly voluntary. From the perspective of economic research, companies need to bear corresponding costs when carrying out carbon disclosure activities. Why are more and more companies willing to bear the costs of carbon disclosure? This phenomenon has caused extensive research by scholars and has become a recent research hotspot in the field of environmental information disclosure.

The research literature generally believes that corporate carbon disclosure is closely related to the financing structure. Companies can use carbon disclosure to transmit information to investors or potential investors to reduce the negative impact caused by information asymmetry and provide them with information on investment decisions. The reduction of information asymmetry by enterprises can play a role in reducing corporate financing costs (Zhou et al,2018; Jung et al, 2018; Bui et al, 2020). The industrial organization theory believes that financing cost is an important factor in corporate innovation. Corporate innovation requires continuous investment of large amounts of capital, and innovation is always accompanied by the risk of failure. If innovation is interrupted, it may lead to innovators' turnover and bring high adjustment costs to innovation activities. Besides, innovation activities are uncertain, but innovation activities, considered as trade secrets, are generally not disclosed to prevent information 
leakage. The resulting information asymmetry and potential moral hazards make the financing costs of innovation activities higher (Hall, 2002). The characteristics of innovative activities make enterprises inevitably face funding problems. According to the optimal structure theory of new structural economics, only a suitable financing structure can meet the financing needs of different industries and enterprises and promote enterprise innovation (Brown et al, 2012). It is worth noting that previous studies to measure enterprise innovation are mostly expressed through R\&D investment, such as Li (2012), Baumann and Kritikos (2016) and R\&D investment mainly reflects the relationship between enterprise technological innovation input and output (Schwartz et al, 2012). However, enterprise innovation includes not only technological progress, it also includes the innovation of many factors such as the knowledge level of material production, management skills, and institutional environment. It is more appropriate to use total factor productivity to measure enterprise innovation. It reflects the nature of productivity as an economic concept, which is the average output level of various input elements in the production process. That is, the overall efficiency of input into the final output (Gatto et al, 2011). So can we find strong empirical evidence to support the mediating effect of corporate financing structure between the quality of carbon disclosure and total factor productivity, to reveal the internal mechanism between the quality of carbon disclosure and total factor productivity?

The above questions urgently need to be answered theoretically and empirically. Therefore, this paper uses listed companies in China's heavily polluting industries as the sample and innovatively analyzes the relationship among the quality of carbon disclosure, financing structure, and total factor productivity, and empirically tests the influence of carbon information disclosure quality on total factor productivity and the mediating effect of financing structure on the relationship between carbon disclosure quality and total factor productivity, and reveals the mechanism of carbon disclosure quality on total factor 
productivity. The research contributions of this paper are as follows: First, most of the existing literature pays more attention to the economic benefits of carbon disclosure quality, while ignoring the relationship between carbon disclosure quality and total factor productivity. The research results in this paper prove that there is a positive relationship between Chinese corporate carbon disclosure quality and total factor productivity. Monetary carbon disclosure quality is better than non-monetary carbon disclosure quality in promoting total factor productivity. Second, The empirical results confirm that the financing structure plays an intermediary effect in the impact of carbon disclosure quality on total factor productivity, and reveals the acting path of carbon disclosure quality affecting total factor productivity. The mediating effect of internal financing capabilities is higher than that of external financing costs. Third, based on the perspective of heterogeneous carbon disclosure quality, it is further verified that the mediating effect of internal financing capabilities in the impact of monetary carbon disclosure quality on total factor productivity is better than that of external financing costs in the impact of non-monetary carbon disclosure quality on total factor productivity. The mediating effect in the process helps to deepen the understanding of the internal mechanism of how carbon disclosure quality affects total factor productivity. The remainder of this study is structured as follows: Section 2 provides the theoretical analysis and research hypotheses. Section 3 presents the research design. Section 4 analyzes the empirical results. Section 5 checks the robustness. Section 5 discusses the conclusions, including general discussion, practical value, and limitations, and future research opportunities.

\section{Theoretical Analysis and Research Hypotheses}

\subsection{Effects of Carbon Disclosure on Total Factor Productivity}

The existing literature mainly focuses on the relationship between carbon disclosure and enterprise innovation, while the research on the relationship between carbon disclosure and enterprise total factor 
110 productivity is rarely seen in the literature. In the real market, information asymmetry will seriously

111 hinder technological innovation. On the one hand, the pre-event asymmetric information of investors

112 will lead to the fact that enterprises can not obtain sufficient financial support for technological

113 innovation, that is, enterprises are forced to give up technological innovation due to financing constraints

114 (Hall and Lerner, 2010). On the other hand, the information asymmetry of investors after the event will

lead to the agent's subjective unwillingness to invest in technological innovation, that is, technological innovation cannot be realized smoothly due to agency problems (Holmstrom, 1989). Voluntary information disclosure theory believes that a higher quality of information disclosure is an important mechanism to reduce the degree of information asymmetry inside and outside the enterprise (Healy and Palepu, 2001). On the one hand, higher quality of information disclosure can reduce investors' prior information disadvantages, improve the external financing environment of companies, and ease financing constraints. On the other hand, higher quality of information disclosure can improve the quality of information obtained by investors in hindsight, reduce the risk of infringement of investors' rights and interests, which will reduce the agency problem. (Balakrishnan et al, 2014). It can be seen that a higher technological innovation. allocation effect (Ren et al, 2019). Technological innovation has a positive effect on total factor productivity and is a key driving force for total factor productivity growth (Hammar and Belarbi).

131 Therefore, Hypothesis 1 is proposed. 

total factor productivity of enterprises.

Corporate carbon disclosure is an important reference for rational investors to make decisions. enterprises have not been unified. According to the content and form of carbon disclosure, it can be roughly divided into monetary carbon disclosure and non-monetary carbon disclosure (Al-Tuwaijri et al., 2004). Monetary carbon disclosure is mainly related to low-carbon scientific research investment, lowcarbon economic benefits, and other monetary indicators, while non-monetary carbon disclosure is related to enterprise low-carbon development strategy, low-carbon publicity activities, low-carbon functional departments, carbon emission accounting, and other written descriptions. The monetary carbon disclosure is directly related to the business performance of the enterprise, and investors can compare and forecast the income through these data, but the non-monetary carbon disclosure is uncertain, two kinds of information to investors' decision-making is different. Hypothesis 2 is proposed.

The corporate financing structure is formed by the diversification of funding sources, which can usually be divided into internal financing and external financing. Internal financing is generated by 
business activities, mainly composed of retained earnings and depreciation. External financing means that companies raise funds through external channels, including bank loans, financial leasing, equity financing, and debt financing. Among them, debt financing is an important financing method for Chinese enterprises. Reducing the cost of debt financing and improving the financing capacity and efficiency of enterprises is an important issue that needs to be solved urgently in the development of Chinese enterprises.

According to the theory of priority financing, internal financing is the first choice for enterprises to improve innovation investment and total factor productivity (Scherer, 2000). In economic transactions and negotiations, different personnel and groups have different levels of information mastery. If they have the higher the level of information integrity, they will be in a dominant position, and it is easier to grasp the initiative of the transaction. The party with an information disadvantage will alleviate the problem of information asymmetry to protect their interests through some restrictions. The party with an information disadvantage will alleviate the problem of information asymmetry through some restrictions, to protect their interests. In the use of retained funds, the enterprise does not need to pay for financing expenses because it does not involve external investors, and the cost is low. At the same time, the approval process is simple and only needs to be approved by the general meeting of shareholders or the board of directors. As a result, the adverse selection problem caused by information asymmetry is greatly reduced, which enables enterprises to concentrate on the investment and operation of innovation projects. The financial manager of the enterprise has a comprehensive grasp of the funds, the management has a detailed plan for the development of the enterprise, and the communication between the two sides is more convenient. It can timely invest in the feasible innovation scheme and do a good job in the use and supervision of the funds. Also, the "investment cash flow sensitivity" effect shows that investment 
expenditure is consistent with the change of internal cash flow, and the more internal funds of enterprises, the greater the promotion effect of innovation investment.

As far as debt financing is concerned, companies generally keep innovation activities confidential, and creditors do not understand the degree of risk in innovation. There is a clear asymmetry between the benefits of corporate innovation and the risks to be assumed. Therefore, reasonable contracts are designed to protect rights and interests. Generally, they will indicate restrictions or increase risk premiums when borrowing, which will increase financing costs and inhibit innovation. The adverse selection also exists in debt financing. Enterprises with poor qualifications will hide some unfavorable information when borrowing. When banks and other financial institutions recover previously issued loans, the companies cannot repay the principal and interest. Such default events increase the risk aversion awareness of loan institutions, strengthen the examination of collateral and increase the loan interest rate, which may lead to other enterprises with good qualifications are eliminated from the credit market. At the same time, more and more small and medium-sized enterprises can not meet the collateral requirements and cannot get loans because of the cumbersome mortgage process of intangible assets. Only assets that can be evaluated can be mortgaged, such as patent ownership and land use right. However, the limited fixed assets of enterprises will restrict bank loans and further worsen the relationship between banks and enterprises.

Therefore, hypothesis 3 , hypothesis $3 \mathrm{a}$, and hypothesis $3 \mathrm{~b}$ are put forward.

Hypothesis 3 Financing structure plays a mediating effect between carbon disclosure quality and total factor productivity

Hypothesis 3a Carbon disclosure quality can reduce corporate debt financing costs and indirectly promote total factor productivity. 

indirectly promote total factor productivity. earnings, while non-monetary carbon disclosure quality has uncertainty, there may be differences in the mechanism of financing structure between heterogeneous carbon disclosure and total factor productivity. This paper further proposes hypothesis 4, hypothesis 5, and hypothesis 6 .

Hypothesis 4 The financing structure has a mediating effect between the quality of nonmonetary carbon disclosure and total factor productivity.

Hypothesis 5 The financing structure has a mediating effect between the quality of monetary carbon disclosure and total factor productivity. and improving internal retained earnings is higher than that of non-monetary carbon disclosure quality. relationship. “-” represents a negative relationship. 


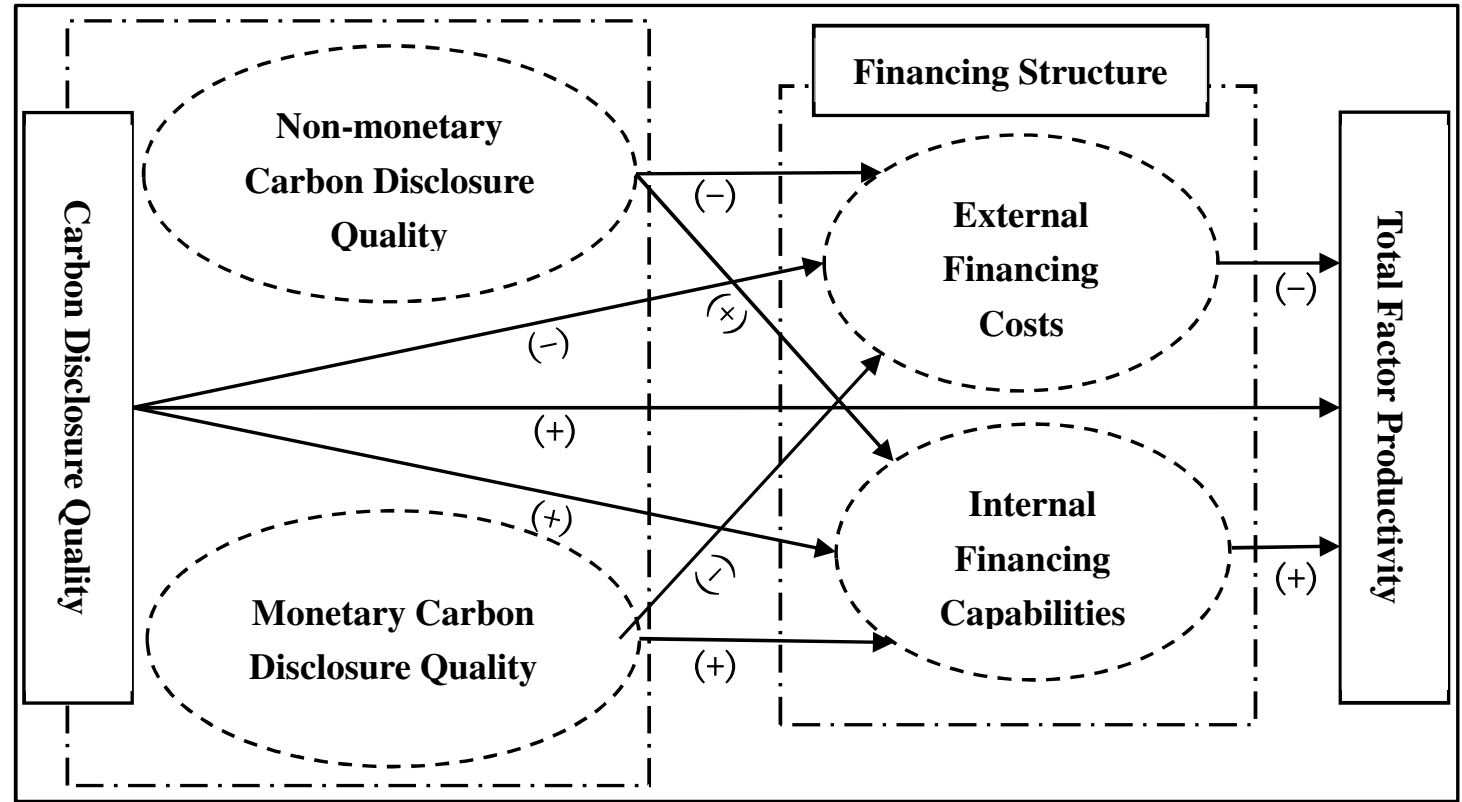

Figure 1. The logic analysis framework

\section{Research Design}

\subsection{Samples}

This paper takes A-share heavy pollution industry enterprises from 2015 to 2018 as the research object. The Chinese context has been selected to investigate the research question because of the rapidly evolving practices regarding financial and non-financial disclosures, which make the evidence of their impact on corporate sustainability of particular relevance for managerial strategic choices in regard to external communication and stakeholder management. The industry classification is mainly based on "the List of Classified Management of Environmental Protection Verification Industry of Listed Companies (2008)" and "Listed Companies Environmental Information Disclosure Guide 2010" promulgated by the Ministry of Environmental Protection of China. Excluding the listed companies with abnormal financial data and missing data, 486 sample companies were finally screened, with a total of 1944 observations. The industry covers 14 industries, including thermal power, coal, metallurgy, chemical industry, petrochemical industry, building materials, papermaking, brewing, pharmaceutical, fermentation, textile, leather and mining, and iron and steel. The 2015-2018 social responsibility report, 
sustainable development report, and relevant environmental report of listed companies are obtained through the RKS database and RESSET database, which are considered as the data source of the carbon disclosure quality. The financial data of listed companies mainly come from the WIND database.

\subsection{Model}

This paper uses the mediating effect test method proposed by MacKinnon et al. (2002) to test the mediating effect of financing structure on the impact of carbon disclosure quality on total factor productivity through two steps.

The first step is the total effect test. The model 1 is used to analyze the total effect of carbon disclosure quality on total factor productivity. The coefficient $\alpha$ represents the impact of carbon disclosure quality on total factor productivity. If $\alpha$ is positive and statistically significant, it indicates that there is a positive relationship between carbon disclosure quality and total factor productivity.

The second step is the mediating effect test, by constructing Model 2 and Model 3 to analyze the impact of carbon disclosure quality on the financing structure, which in turn affects the company's total factor productivity. Model 2 measures whether there is a mediating effect in the financing structure, if $\varphi$ is significant, it means that there is a mediating effect in the financing structure. Model 3 measures the direct effect of carbon disclosure quality on total factor productivity, if $\gamma$ is not Significant, while $\rho$ is significant, it means that the financing structure has a completely mediating effect in the impact of carbon disclosure quality on total factor productivity. If both $\rho$ and $\gamma$ are significant, it means that the financing structure has a partial mediating effect.

$$
T F P_{i, t}=\beta_{0}+\alpha C D_{i, t}+\sum_{i=1}^{10} \beta_{i} C V_{i, t}+\varepsilon_{i, t}
$$

$$
F S_{i, t}=\beta_{0}^{\prime}+\varphi C D_{i, t}+\sum_{i=1}^{10} \beta_{i}^{\prime} C V_{i, t}+\varepsilon_{i, t}^{\prime}
$$



represents the carbon disclosure quality of the listed company $i$ at period $t, F S_{i, t}$ represents the financing structure of the listed company $i$ at period $t$, and $C V_{i, t}$ represents the control variable. $Z=\hat{\varphi} \hat{\rho} / S_{\varphi \rho}, \quad \hat{\varphi}_{\text {and }} \hat{\rho}$ are estimates of $\varphi_{\text {and }} \rho_{\text {respectively. }} S_{\varphi \rho}=\sqrt{\hat{\varphi}^{2} S_{\rho}^{2}+\hat{\rho}^{2} S_{\varphi}^{2}}$ is the standard error of $\hat{\varphi} \hat{\rho} . S_{\varphi}$ and $S_{\rho}$ are the standard errors of $\hat{\varphi}$ and $\hat{\rho}$ respectively.

It is worth mentioning that the mediating effect test model of the quality of non-monetary carbon disclosure and monetary carbon disclosure is consistent with that of carbon disclosure quality. We need only to replace the quality of carbon disclosure with that of non-monetary carbon disclosure and monetary carbon disclosure. Thus, we will not repeat the model of the mediating effect test.

\subsection{Variable Description}

\subsubsection{Dependent Variable: Total Factor Productivity}

Olley and Pakes (1996) first used the semiparametric estimator to measure the productivity of micro-

enterprises. This method uses investment as the proxy variable of productivity shocks to solve the simultaneous bias, and uses the survival probability to solve the sample selection bias. Then Levinsohn and Petrin (2003) pointed out the following problems in using investment as a proxy variable in the OP model: on the one hand, there are adjustment costs in enterprises, which make the investment amount of some enterprises zero. Assuming that there is a monotonic increasing relationship between investment and total output, it shows that the data with zero investment amount can not be estimated, which makes a large number of sample data unavailable; on the other hand, there is non-convex adjustment cost, which makes the error term and investment correlate, resulting in investment can not fully respond to the impact 
of productivity. LP model uses intermediate input as a proxy variable and considers that compared with investment as a proxy variable, the sample size loss of intermediate input is less, which can better solve the endogenous problem of production function and obtain the consistent and effective estimation of input factors. Therefore, this paper chooses the LP method to measure the total factor productivity of enterprises, in which the output is expressed by the total operating income, the labor input is measured by the total number of employees, the capital input is expressed by the net fixed assets value of the enterprise, and the cash paid for purchasing goods and receiving services is taken as the proxy variable of intermediate input. Besides, Blundell and bond (1998) effectively solved the endogenous problem in regression by adding instrumental variables into GMM estimation. This method has been recognized by many scholars (Tebaldi et al., 2017). Therefore, this paper selects the GMM method as a robustness test.

\subsubsection{Explanatory Variables: Carbon Disclosure Index}

Carbon information is a non-mandatory disclosure project, so the concept and content of carbon information have not yet formed a unified standard (Hoffmann and Busch, 2008). Scholars have carried out in-depth research on the construction of carbon disclosure framework and system based on different academic positions and professional knowledge. The evaluation methods of carbon information mainly include the reputation scoring method and content analysis method. The reputation scoring method is to issue questionnaires to stakeholders, and the stakeholders will score the reputation of the object to be evaluated, or the authoritative organization will evaluate the relevant information of the enterprise. The disadvantage of this method is that the evaluation results largely depend on the respondents' understanding of the enterprise, and is limited by the scale of the company, the brand, the personal experience, and the ability of the respondents. It is easy to produce biased evaluation, and even lead to different evaluation conclusions because of the subjective factors of the respondents. The content 
analysis method is to evaluate the information disclosure level of the company by analyzing and identifying the relevant contents of various report documents published by the company. This method has the obvious advantages of accessibility, openness, effectiveness, testability, but the disadvantage is that the workload is large, and there is a certain subjectivity in the content analysis. Due to the lack of authoritative reputation survey data in China, content analysis is relatively a better method. The most influential one is the Carbon Disclosure Project (CDP). Most of the studies are based on the CDP carbon information reports provided by the world's top 500 enterprises (Choi et al. 2013). Although the number of enterprises participating in CDP has increased rapidly in recent years and the data is increasing, the number of carbon information disclosed by Chinese enterprises participating in CDP projects is very few, which makes this paper have to think about the applicability of the project in China and the necessity of building a more unified and accurate carbon disclosure framework.

Chinese enterprises is in the initial stage, based on the research content of the CDP, and draws on the corporate carbon disclosure method of Li et al. (2017) to construct carbon indicator system suitable for disclosure includes both monetary carbon disclosure and non-monetary carbon information disclosure (Aerts et al., 2009). Because of this, this article measures the quality of non-monetary carbon disclosure through low-carbon strategic awareness, low-carbon management departments, low-carbon publicity activities, carbon emission reduction accounting, carbon emission reduction standards, and low-carbon performance evaluation. Other remaining indicators represent the quality of monetary carbon disclosure, and the specific accounting methods are as follows: 


$$
N M C D_{i}=\frac{\sum_{i=1}^{6} N M C D P_{i}}{N M T P}
$$

$$
M C D_{i}=\frac{\sum_{i=1}^{3} M C D P_{i}}{M T P}
$$

monetary carbon disclosure quality, and monetary carbon disclosure quality. $\sum_{i=1}^{9} C D P_{i}$ represents the sum of the scores of listed company $i^{\prime} s$ carbon disclosure projects. $\sum_{i=1}^{6} N M C D P_{i}$ indicates the sum of scores of listed company $i^{\prime} s$ non-monetary carbon disclosure project. $\sum_{i=1}^{3} M C D P_{i}$ indicates the sum of scores of listed company $i^{\prime} s$ monetary carbon disclosure project. TP,NMTP, and $M T P$ respectively represent the sum of the highest scores of enterprise carbon disclosure, the sum of the highest scores of non-monetary carbon disclosure, and the sum of the highest scores of monetary carbon disclosure. According to table 1, the specific scores of $T P, N M T P$, and $M T P$ are 14, 8, and 6 . Table 1 Corporate Carbon Information Disclosure Evaluation Index System

\begin{tabular}{cclc}
\hline Classification & Evaluation index & \multicolumn{1}{c}{ Points description } & score \\
\hline & $\begin{array}{c}\text { low-carbon } \\
\text { strategic awareness } \\
\text { low-carbon }\end{array}$ & $\begin{array}{l}\text { Having a low-carbon development strategy records } \\
\text { 1, otherwise 0 }\end{array}$ & 1 \\
management & Setting a low-carbon management department & 1 \\
monetary carbon & records 1, otherwise 0 & \\
disclosure & low-carbon & Having a low-carbon publicity activity records 1, & 1 \\
& publicity activities & otherwise 0 & \\
& carbon emission & Simple qualitative disclosure records 1, detailed & 3 \\
& reduction & qualitative disclosure records 1.5, simple
\end{tabular}




\begin{tabular}{|c|c|c|c|}
\hline & accounting & $\begin{array}{l}\text { quantitative and quantitative disclosure records } 2 \text {, } \\
\text { detailed qualitative and quantitative disclosure } \\
\text { records } 3 \text {, otherwise } 0\end{array}$ & \\
\hline & $\begin{array}{l}\text { carbon emission } \\
\text { reduction standards }\end{array}$ & $\begin{array}{l}\text { Having a government's approval records } 1 \text {, } \\
\text { otherwise } 0\end{array}$ & 1 \\
\hline & $\begin{array}{l}\text { low-carbon } \\
\text { performance } \\
\text { evaluation }\end{array}$ & $\begin{array}{l}\text { Including a performance appraisal records } 1 \text {, } \\
\text { otherwise } 0\end{array}$ & 1 \\
\hline & $\begin{array}{l}\text { low-carbon research } \\
\text { achievements }\end{array}$ & $\begin{array}{l}\text { Qualitative disclosure records } 1 \text {, quantitative and } \\
\text { quantitative disclosure records } 2 \text {, otherwise } 0\end{array}$ & 2 \\
\hline $\begin{array}{l}\text { the quality of } \\
\text { monetary carbon }\end{array}$ & $\begin{array}{l}\text { Clean energy } \\
\text { utilization benefits }\end{array}$ & $\begin{array}{l}\text { Qualitative disclosure records } 1 \text {, quantitative and } \\
\text { quantitative disclosure records } 2 \text {, otherwise } 0\end{array}$ & 2 \\
\hline disciosure & $\begin{array}{l}\text { Low-carbon } \\
\text { economic benefits }\end{array}$ & $\begin{array}{l}\text { Qualitative disclosure records } 1 \text {, quantitative and } \\
\text { quantitative disclosure records } 2 \text {, otherwise } 0\end{array}$ & 2 \\
\hline
\end{tabular}

\subsubsection{Mediating Variables: Financing Structure}

Internal financing capabilities. Internal financing capabilities reflect the abilities of enterprises to obtain funds from the inside, which mainly come from the retained earnings accumulated in the process of business operation and the extracted depreciation, and the retained earnings include surplus accumulation fund and undistributed profit. Therefore, this paper expresses the company's internal financing capabilities by using the proportion of the sum of the surplus reserve, undistributed profit, and depreciation cost to total assets. external financing. The existing research mostly uses debt rating and average yield to maturity to measure the cost of debt financing (Schneider,2011; Aldamen and Duncan 2013). However, China's capital market system is still in the reform stage, and there is no authoritative debt rating, nor does it provide different types of debt interest, such as bank loans, bonds, notes payable. So this paper uses the calculation method of Pittman and Fortin (2004), Li and Liu (2009) to calculate the debt financing cost of listed companies by the proportion of total interest expenditure to the average value of long-term and short-term debt. 

year, long-term loans, bonds payable, long-term payables, and other long-term liabilities.

\subsubsection{Control Variables}

The control variables in this article mainly include Equity concentration (ER), Listing Period (LP),

Company Size (CS), Return on Assets (ROA), Debt-paying Ability (DPA), Risk Level (RL), Growth

Ability (GA), Asset-liability Ratio (ALR), Sales Cash Ratio (SCR), Operating Leverage (OL)(Gray et

\begin{tabular}{|c|c|c|}
\hline Symbol & Name & Description \\
\hline TFP & total factor productivity & TFP is calculated by the LP method and GMM method \\
\hline $\mathrm{CD}$ & Carbon disclosure quality & $\mathrm{CD}$ is calculated by formula 4 \\
\hline NMCD & $\begin{array}{l}\text { Non-mandatory carbon } \\
\text { disclosure quality }\end{array}$ & NMCD is calculated by formula 5 \\
\hline MCD & $\begin{array}{l}\text { Monetary carbon disclosure } \\
\text { quality }\end{array}$ & MCD is calculated by formula 6 \\
\hline DFC & Debt financing cost & $\begin{array}{l}\text { Total interest expense/Average long-term and short-term } \\
\text { debt }\end{array}$ \\
\hline RER & Retained earnings ratio & $\begin{array}{l}\text { (Surplus reserve+Undistributed profit+Depreciation } \\
\text { cost)/ Total assets }\end{array}$ \\
\hline ER & Equity concentration & $\begin{array}{l}\text { The proportion of the number of shares held by the top } \\
\text { ten shareholders in the total share capital of the company }\end{array}$ \\
\hline LP & Listing period & Reporting time-listing time \\
\hline CS & Company size & The logarithm of total assets \\
\hline ROA & Return on assets & $\begin{array}{l}\text { Retained profits/(Total assets at the beginning of the } \\
\text { period+Total assets at the end of the period) } / 2\end{array}$ \\
\hline DPA & Debt-paying ability & Net cash flow from operating activities/Total liability \\
\hline RL & Risk level & $\beta$ coefficient \\
\hline GA & Growth ability & The growth rate of total operating revenue \\
\hline ALR & Asset-liability ratio & Gross liability/Total assets \\
\hline SCR & Sales cash ratio & $\begin{array}{l}\text { Net cash flow from operating activities/Operation } \\
\text { revenue }\end{array}$ \\
\hline $\mathrm{OL}$ & Operating leverage & Fixed assets/Total assets \\
\hline
\end{tabular}




\subsection{Pearson Correlation Analysis}

To avoid pseudo-regression in subsequent regression analysis, this paper tests the correlation and

collinearity between variables in advance. It can be seen from Table 3 that all explanatory variables, excepting for GA, are significant at the $5 \%$ level of significance, indicating that each variable has a high correlation with the firm's total factor productivity. The CD, NMCD, MCD, RER, ER, LP, CS, ROA, ALR, SCR, and TFP have a significant positive correlation. The DFC, DPA, and RL are significantly negatively correlated with TFP. The GA is positively correlated with TFP, but it fails to pass the significance test. This preliminarily shows that the improvement in the quality of corporate carbon disclosure has promoted the increase in total factor productivity, while the increase in debt financing costs and the decline in the retained earnings ratio have restricted the increase in total factor productivity.

Due to the significant correlation coefficients among some variables, the possible multicollinearity problem between variables was further examined. It can be seen from Table 3 that the variance inflation factor of each variable is lower than 3 , so it can be concluded that the model does not have a serious multicollinearity problem. In summary, the selection of variables in this article is reasonable and representative.

Table 3 Variable descriptive statistics and correlation analysis results

\begin{tabular}{ccccccccc}
\hline Variable & Mean & Std. Dev. & Min & Max & Pearson & VIF & VIF1 & VIF2 \\
\hline TFP & 0.543 & 1.034 & -4.457 & 3.964 & 1.000 & & & \\
CD & 0.575 & 0.245 & 0 & 1 & $0.507^{* * *}$ & 1.46 & & \\
NMCD & 0.523 & 0.285 & 0 & 1 & $0.455^{* * *}$ & & 1.33 & \\
MCD & 0.645 & 0.268 & 0 & 1 & $0.437^{* * *}$ & & & 1.36 \\
DFC & 0.020 & 0.044 & 0 & 0.697 & $-0.195^{* * * *}$ & 1.46 & 1.45 & 1.46 \\
RER & 0.383 & 0.266 & -2.473 & 1.307 & $0.282^{* * *}$ & 1.55 & 1.52 & 1.56 \\
ER & 0.354 & 0.148 & 0 & 0.891 & $0.301^{* * *}$ & 1.21 & 1.21 & 1.21 \\
LP & 12.068 & 6.987 & -1 & 30 & $0.271^{* * *}$ & 1.13 & 1.14 & 1.13 \\
& & & & 19 & & & &
\end{tabular}




\begin{tabular}{ccccccccc} 
CS & 4.116 & 1.343 & 0.464 & 8.678 & $0.807 * * *$ & 2.10 & 2.08 & 1.95 \\
ROA & 0.071 & 0.076 & -0.647 & 0.534 & $0.092 * * *$ & 1.65 & 1.65 & 1.65 \\
DPA & 0.248 & 0.426 & -1.545 & 4.465 & $-0.059 * * *$ & 2.35 & 2.35 & 2.35 \\
RL & 1.103 & 0.354 & -0.106 & 2.441 & $-0.047 * *$ & 1.03 & 1.02 & 1.03 \\
GA & 0.147 & 0.332 & -0.721 & 4.140 & 0.004 & 1.16 & 1.16 & 1.16 \\
ALR & 0.399 & 0.197 & 0.319 & 0.989 & $0.393 * * *$ & 2.03 & 2.03 & 2.07 \\
SCR & 0.121 & 0.186 & -3.324 & 1.379 & $0.092 * * *$ & 1.59 & 1.59 & 1.59 \\
OL & 0.514 & 0.182 & 0.014 & 0.962 & $0.118 * * *$ & 1.35 & 1.35 & 1.36 \\
\hline
\end{tabular}

Note: $* * *, * * *$ represent significant at the significance level of $1 \%, 5 \%$, and $10 \%$ respectively.

\subsection{Test of Mediating Effect of Financing Structure Between Carbon Disclosure and Total Factor}

\section{Productivity}

This paper uses the Sgmediation command of Stata14 to test the mediating effect. Table 4 reports the

total effect of carbon disclosure quality on total Factor productivity and the mediation effect of financing

structure between carbon disclosure quality and total Factor productivity. From the results of Sobel's test,

it can be seen that the debt financing cost and retained earnings ratio rejected the null hypothesis, and

confirmed that the debt financing cost and retained earnings ratio play a mediating effect on the impact

of carbon disclosure quality on the total factor productivity. Hypothesis $\mathrm{H} 3$ can be confirmed. By

Table 4 The regression results of carbon disclosure quality and enterprise total factor productivity from the perspective of financing structure

\begin{tabular}{lccccc}
\hline & Total effect & \multicolumn{2}{c}{ Mediating effect } & \multicolumn{2}{c}{ Mediating effect } \\
\hline \multirow{2}{*}{ Variables } & $(1)$ & $(2)$ & $(3)$ & $(4)$ & $(5)$ \\
\hline CD & TFP & DFC & TFP & RER & TFP \\
\hline & $0.437 * * *$ & $-0.011^{* * *}$ & $0.404^{* * *}$ & $0.179^{* * *}$ & $0.367 * * *$ \\
& $(6.71)$ & $(-2.70)$ & $(6.30)$ & $(7.00)$ & $(5.63)$
\end{tabular}




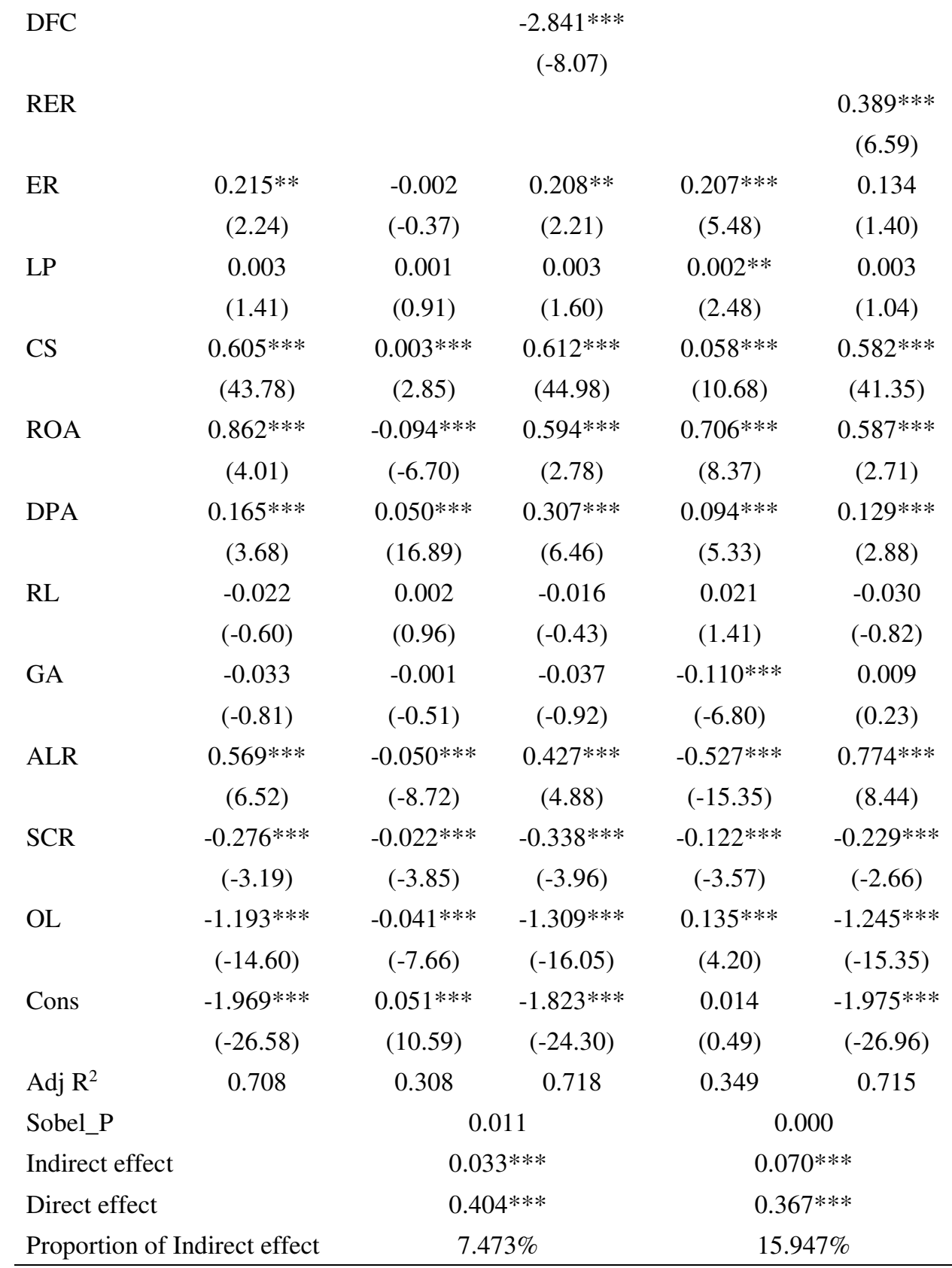

389 Note: $* * * * *, *$ represent significant at the significance level of $1 \%, 5 \%$, and $10 \%$ respectively. the 390 T statistics are in parentheses. of carbon disclosure on total factor productivity. The result of Equation 1 shows that the coefficient of carbon disclosure quality is 0.437 , which is highly significant at the $1 \%$ significance level, indicating that high-quality carbon disclosure can effectively promote the improvement of total factor productivity. 

we continue to test the mediating effect. In the second step, we get the equation 2 to equation 5 . Equation 2 and equation 3 are used to test the effect of carbon disclosure quality on debt financing cost and whether there is a mediating effect on debt financing cost. Equation 5 and equation 6 are used to test the effect of carbon disclosure quality on retained earnings ratio and whether there is a mediating effect on retained earnings ratio

in Equation 3 all pass the 1\% significance test. The debt financing cost has a reverse relationship with total factor productivity, and the quality of carbon disclosure has a positive relationship with total factor and indirectly promote total factor productivity. Hypothesis H3a can be verified.

The regression coefficient of carbon disclosure quality in Equation 4 is 0.179, which has passed the $1 \%$ significance test. The regression coefficients of carbon disclosure quality and retained earnings ratio be verified. and the mediating effect of financing structure on the relationship between non-monetary carbon 
earnings ratio have a mediating effect on the impact of non-monetary carbon disclosure quality on total factor productivity. Hypothesis 4 can be verified. From the mediating effect coefficient, the mediating effect coefficient of retained earnings ratio is significantly higher than that of debt financing cost, indicating that the mediating effect of retained earnings ratio between the quality of non-monetary carbon disclosure and total factor productivity is better than that of debt financing cost.

According to regression equation 1 , the regression coefficient of non-monetary carbon disclosure quality is 0.275 , which is significantly positive, indicating that the quality of non-monetary carbon information disclosure is positively related to total factor productivity, and high-quality non-monetary carbon information disclosure can promote the increase of total factor productivity. Equation 2 and equation 3 are used to test the mechanism between the quality of non-monetary carbon disclosure and the cost of debt financing, and whether there is a mediating effect of debt financing cost. In equation 2 , there is a reverse relationship between the quality of non-monetary carbon disclosure and the cost of debt financing. The regression coefficient in equation 3 between the quality of non-monetary carbon disclosure and the cost of debt financing passes the significance test of $1 \%$. The mechanism of the two factors on total factor productivity is the opposite, indicating that debt financing costs have a mediating effect on the quality of non-monetary carbon disclosure and total factor productivity. Equation 4 and equation 5 test the relationship between the quality of non-monetary carbon disclosure and the retained earnings ratio, as well as whether the retained earnings ratio has a mediating effect. The regression coefficient of the quality of non-monetary carbon disclosure in Equation 4 is significant at a significance level of $1 \%$. The quality of non-monetary carbon disclosure and the ratio of retained earnings in Equation 5 both pass the significance test. The performance for total factor productivity is the positive driving effect indicates that the retained earnings ratio has a mediating effect on the quality of non-monetary 
Table 5 The regression results of non-monetary carbon disclosure quality and enterprise total factor productivity from the perspective of financing structure

\begin{tabular}{|c|c|c|c|c|c|}
\hline & \multirow{2}{*}{$\begin{array}{c}\text { Total effect } \\
(1)\end{array}$} & \multicolumn{2}{|c|}{ Mediating effect } & \multicolumn{2}{|c|}{ Mediating effect } \\
\hline & & (2) & (3) & (5) & (6) \\
\hline Variables & TFP & DFC & TFP & RER & TFP \\
\hline \multirow[t]{2}{*}{ NMCD } & $0.275^{* * *}$ & $-0.006^{*}$ & $0.257 * * *$ & $0.097 * * *$ & $0.235^{* * *}$ \\
\hline & $(5.12)$ & $(-1.82)$ & $(4.86)$ & $(4.60)$ & $(4.40)$ \\
\hline \multirow[t]{2}{*}{ DFC } & & & $-2.908 * * *$ & & \\
\hline & & & $(-8.23)$ & & \\
\hline \multirow[t]{2}{*}{ RER } & & & & & $0.415^{* * *}$ \\
\hline & & & & & $(7.06)$ \\
\hline \multirow[t]{2}{*}{ ER } & $0.223 * *$ & -0.003 & $0.216^{* *}$ & $0.212 * * *$ & 0.135 \\
\hline & $(2.31)$ & $(-0.42)$ & $(2.27)$ & $(5.56)$ & $(1.41)$ \\
\hline \multirow[t]{2}{*}{ LP } & 0.003 & 0.001 & 0.003 & $0.002 * *$ & 0.002 \\
\hline & $(1.36)$ & $(0.89)$ & $(1.56)$ & $(2.51)$ & $(0.97)$ \\
\hline \multirow[t]{2}{*}{$\mathrm{CS}$} & $0.615 * * *$ & $0.002 * *$ & $0.622 * * *$ & $0.064 * * *$ & $0.589 * * *$ \\
\hline & $(44.77)$ & $(2.47)$ & $(45.98)$ & $(11.79)$ & $(41.84)$ \\
\hline \multirow[t]{2}{*}{ ROA } & $0.875 * * *$ & $-0.094 * * *$ & $0.600 * * *$ & $0.711 * * *$ & $0.580 * * *$ \\
\hline & $(4.06)$ & $(-6.71)$ & $(2.80)$ & $(8.37)$ & $(2.67)$ \\
\hline \multirow[t]{2}{*}{ DPA } & $0.164 * * *$ & $0.050 * * *$ & $0.308 * * *$ & $0.094 * * *$ & $0.125^{* * *}$ \\
\hline & (3.63) & $(16.88)$ & $(6.46)$ & $(5.27)$ & $(2.78)$ \\
\hline \multirow[t]{2}{*}{ RL } & -0.010 & 0.002 & -0.005 & $0.027 *$ & -0.021 \\
\hline & $(-0.28)$ & $(0.81)$ & $(-0.12)$ & $(1.80)$ & $(-0.58)$ \\
\hline \multirow[t]{2}{*}{ GA } & -0.038 & -0.001 & -0.042 & $-0.112 * * *$ & 0.008 \\
\hline & $(-0.93)$ & $(-0.46)$ & $(-1.04)$ & $(-6.89)$ & $(0.19)$ \\
\hline \multirow[t]{2}{*}{ ALR } & $0.603 * * *$ & $-0.051 * * *$ & $0.456 * * *$ & $-0.514 * * *$ & $0.816^{* * *}$ \\
\hline & $(6.87)$ & $(-8.85)$ & $(5.17)$ & $(-14.85)$ & $(8.90)$ \\
\hline \multirow[t]{2}{*}{ SCR } & $-0.274 * * *$ & $-0.022 * * *$ & $-0.337 * * *$ & $-0.121 * * *$ & $-0.224 * *$ \\
\hline & $(-3.15)$ & $(-3.86)$ & $(-3.93)$ & $(-3.53)$ & $(-2.60)$ \\
\hline \multirow[t]{2}{*}{ OL } & $-1.170 * * *$ & $-0.042 * * *$ & $-1.291 * * *$ & $0.144 * * *$ & $-1.230 * * *$ \\
\hline & $(-14.26)$ & $(-7.77)$ & $(-15.76)$ & $(4.46)$ & $(-15.11)$ \\
\hline \multirow[t]{2}{*}{ Cons } & $-1.946^{* * *}$ & $0.051 * * *$ & $-1.798 * * *$ & 0.024 & $-1.956 * * *$ \\
\hline & $(-26.16)$ & (10.47) & $(-23.90)$ & $(0.82)$ & $(-26.64)$ \\
\hline$A d j \_R^{2}$ & 0.705 & 0.306 & 0.716 & 0.339 & 0.713 \\
\hline \multicolumn{2}{|l|}{ Sobel_P } & \multicolumn{2}{|c|}{0.075} & \multicolumn{2}{|c|}{0.000} \\
\hline \multicolumn{2}{|l|}{ Indirect effect } & \multicolumn{2}{|c|}{$0.019 * * *$} & \multicolumn{2}{|c|}{$0.040 * * *$} \\
\hline \multicolumn{2}{|l|}{ Direct effect } & \multicolumn{2}{|c|}{$0.257 * * *$} & \multicolumn{2}{|c|}{$0.235 * * *$} \\
\hline \multicolumn{2}{|c|}{ Proportion of Indirect effect } & & $7 \%$ & 14. & $0 \%$ \\
\hline
\end{tabular}

445 Note: $* * *, * * *$ represent significant at the significance level of $\mathbf{1 \%}, \mathbf{5 \%}$, and $\mathbf{1 0 \%}$ respectively. 446 The $\mathbf{T}$ statistics are in parentheses. 
4.4 Test of Mediating Effect of Financing Structure Between Monetary Carbon Disclosure and

Total Factor Productivity

Table 6 reports the total effect of monetary carbon disclosure quality on total factor productivity and

the mediating effect of financing structure on the relationship between monetary carbon disclosure

quality and total factor productivity. The Sobel test cannot accept the null hypothesis, which shows that debt financing cost and retained earnings ratio also have a mediating effect on the impact of monetary carbon disclosure quality on total factor productivity. Hypothesis 5 can be verified. From the mediating effect coefficient, the mediating effect coefficient of retained earnings ratio is always higher than that of debt financing cost.

In the total effect regression results, the regression coefficient of monetary carbon disclosure quality is 0.366 , which has passed the significance test of $1 \%$, and it is significantly higher than that of nonmonetary carbon disclosure quality, indicating that the promotion effect of monetary carbon disclosure

effect of debt financing cost. In equation 2, the regression coefficient of monetary carbon disclosure 

positive, indicating that the retained earnings ratio also plays a mediating effect in monetary carbon disclosure quality and total factor productivity.

Table 6 The regression results of monetary carbon disclosure quality and enterprise total

\begin{tabular}{|c|c|c|c|c|c|}
\hline & \multirow{2}{*}{$\frac{\text { Total effect }}{(1)}$} & \multicolumn{2}{|c|}{ Mediating effect } & \multicolumn{2}{|c|}{ Mediating effect } \\
\hline & & (2) & (3) & (5) & (6) \\
\hline Variables & TFP & $\mathrm{DFC}$ & TFP & RER & TFP \\
\hline MCD & $\begin{array}{c}0.366^{* * * *} \\
(6.40)\end{array}$ & $\begin{array}{c}-0.011 * * * \\
(-2.92)\end{array}$ & $\begin{array}{c}0.335 * * * \\
(5.95)\end{array}$ & $\begin{array}{c}0.174 * * * \\
(7.76)\end{array}$ & $\begin{array}{c}0.299 * * * \\
(5.20)\end{array}$ \\
\hline $\mathrm{DFC}$ & & & $\begin{array}{c}-2.838 * * * \\
(-8.05)\end{array}$ & & \\
\hline RER & & & & & $\begin{array}{c}0.387 * * * \\
(6.54)\end{array}$ \\
\hline ER & $\begin{array}{c}0.223^{* *} \\
(2.32)\end{array}$ & $\begin{array}{l}-0.002 \\
(-0.40)\end{array}$ & $\begin{array}{c}0.216^{* *} \\
(2.29)\end{array}$ & $\begin{array}{c}0.209 * * * \\
(5.56)\end{array}$ & $\begin{array}{l}0.142 \\
(1.48)\end{array}$ \\
\hline LP & $\begin{array}{c}0.004 * * \\
(1.96)\end{array}$ & $\begin{array}{l}0.001 \\
(0.70)\end{array}$ & $\begin{array}{c}0.004 * * \\
(2.12)\end{array}$ & $\begin{array}{c}0.003 * * \\
(3.06)\end{array}$ & $\begin{array}{l}0.003 \\
(1.51)\end{array}$ \\
\hline $\mathrm{CS}$ & $\begin{array}{c}0.617 * * * \\
(46.49)\end{array}$ & $\begin{array}{c}0.002 * * * \\
(2.71)\end{array}$ & $\begin{array}{c}0.623 * * * \\
(47.71)\end{array}$ & $\begin{array}{c}0.061 * * * \\
(11.80)\end{array}$ & $\begin{array}{c}0.593 * * * \\
(43.57)\end{array}$ \\
\hline ROA & $\begin{array}{c}0.842 * * * \\
(3.92)\end{array}$ & $\begin{array}{c}-0.094 * * * \\
(-6.66)\end{array}$ & $\begin{array}{c}0.577 * * * \\
(2.70)\end{array}$ & $\begin{array}{c}0.697 * * * \\
(8.28)\end{array}$ & $\begin{array}{c}0.573 * * * \\
(2.64)\end{array}$ \\
\hline DPA & $\begin{array}{c}0.172 * * * \\
(3.83)\end{array}$ & $\begin{array}{c}0.049 * * * \\
(16.84)\end{array}$ & $\begin{array}{c}0.313 * * * \\
(6.59)\end{array}$ & $\begin{array}{c}0.097 * * * \\
(5.52)\end{array}$ & $\begin{array}{c}0.135^{* * *} \\
(3.01)\end{array}$ \\
\hline RL & $\begin{array}{l}-0.020 \\
(-0.53)\end{array}$ & $\begin{array}{l}0.002 \\
(0.98)\end{array}$ & $\begin{array}{l}-0.013 \\
(-0.36)\end{array}$ & $\begin{array}{l}0.020 \\
(1.37)\end{array}$ & $\begin{array}{l}-0.028 \\
(-0.75)\end{array}$ \\
\hline GA & $\begin{array}{l}-0.028 \\
(-0.69)\end{array}$ & $\begin{array}{l}-0.002 \\
(-0.57)\end{array}$ & $\begin{array}{l}-0.033 \\
(-0.81)\end{array}$ & $\begin{array}{c}-0.107 * * * \\
(-6.66)\end{array}$ & $\begin{array}{l}0.013 \\
(0.32)\end{array}$ \\
\hline ALR & $0.519 * * *$ & $-0.048 * * *$ & $0.382 * * *$ & $-0.551 * * *$ & $0.732 * * *$ \\
\hline
\end{tabular}




\begin{tabular}{lccccc} 
& $(5.90)$ & $(-8.41)$ & $(4.33)$ & $(-16.02)$ & $(7.89)$ \\
SCR & $-0.284 * * *$ & $-0.022 * * *$ & $-0.345^{* * *}$ & $-0.125 * * *$ & $-0.236 * * *$ \\
& $(-3.28)$ & $(-3.82)$ & $(-4.04)$ & $(-3.69)$ & $(-2.74)$ \\
OL & $-1.214 * * *$ & $-0.040^{* * *}$ & $-1.328 * * *$ & $0.123 * * *$ & $-1.262^{* * *}$ \\
& $(-14.81)$ & $(-7.50)$ & $(-16.23)$ & $(3.84)$ & $(-15.50)$ \\
Cons & $-1.991 * * *$ & $0.052 * * *$ & $-1.843 * * *$ & 0.002 & $-1.992^{* * *}$ \\
& $(-26.75)$ & $(10.71)$ & $(-24.44)$ & $(0.08)$ & $(-27.07)$ \\
Adj_R ${ }^{2}$ & 0.708 & 0.308 & 0.718 & 0.353 & 0.714 \\
Sobel_P & & \multicolumn{2}{c}{0.006} & 0.000 \\
Indirect effect & & \multicolumn{2}{c}{$0.031^{* * *}$} & $0.067 * * *$ \\
Direct effect & & $0.335^{* * *}$ & $0.299 * * *$ \\
Proportion of Indirect effect & \multicolumn{2}{c}{$8.461 \%$} & \multicolumn{2}{c}{$18.389 \%$} \\
\hline
\end{tabular}

480

\section{Robust Test}

\subsection{Control of Endogenous Problems}

There may be endogenous problems between enterprise carbon disclosure, non-monetary carbon disclosure, monetary carbon disclosure, and enterprise total factor productivity. Considering the interference of endogenous problems on the regression results, this paper uses the IV estimation method and refers to the method of Larcker and Rusticus (2010), with the average carbon disclosure quality, nonmonetary carbon disclosure quality, monetary carbon disclosure quality, and other control variables reflecting enterprise operation at the beginning of the research object as the instrument variables, because it is related to carbon information disclosure, but it is unlikely to directly affect the total factor productivity of a single enterprise is modest. It can be seen from Table 7 that both Anderson canon. Cor. LM statistic and Sargan statistic reject the original hypothesis, indicating that there is no problem of under-identification and overidentification for instrument variables, and Cragg Donald Wald F Statistic accepts the original hypothesis, proving that there is a certain correlation between instrument variables and carbon disclosure, non-monetary carbon disclosure and monetary carbon disclosure, and there is no 
weak instrumental variable. The regression coefficients of carbon disclosure quality, non-monetary carbon disclosure quality, monetary carbon disclosure quality, and total factor productivity in equation 1 to equation 3 are still significantly positive, indicating that the positive change relationship between carbon disclosure quality, non-monetary carbon disclosure quality, monetary carbon disclosure quality, and total factor productivity has never changed. The results remain consistent with the aforementioned results.

Table 7 Endogenous test results of corporate carbon disclosure quality and total factor

\begin{tabular}{cccc}
\multicolumn{4}{c}{ productivity } \\
Variables & $(1)$ & $(2)$ & $(3)$ \\
& TFP & TFP & TFP \\
\hline CD & $2.282^{* * *}$ & & \\
& $(18.52)$ & & \\
NMCD & & $1.623^{* * *}$ & \\
& & $(18.26)$ & \\
MCD & & $4.415^{* * *}$ \\
& & & $(10.81)$ \\
Anderson canon. corr. LM statistic & $517.525^{* * *}$ & $511.501^{* * *}$ & $133.429^{* * *}$ \\
Cragg-Donald Wald F statistic & $83.571^{* * *}$ & $82.000^{* * *}$ & $14.705^{* *}$ \\
Sargan statistic & $54.209^{* * *}$ & $56.414^{* * *}$ & $29.869^{* * * *}$ \\
\hline
\end{tabular}
Note: $* * *, * * *$ represent significant at the significance level of $1 \%, 5 \%$, and $10 \%$ respectively.The $\mathrm{Z}$ statistics are in parentheses.

\subsection{Substitution of Dependent Variable}

To test the robustness of the research conclusions, this study uses the GMM method to recalculate the company's total factor productivity, replacing the dependent variable TFP. Table 8, Table 9, and Table 10 report the total effect of carbon disclosure quality and heterogeneous carbon disclosure quality on total essential productivity, and test the mediating effect of financing structure on carbon disclosure quality, heterogeneous carbon disclosure quality, and total factor productivity. The regression results are 
Table8 The regression results of carbon disclosure quality and enterprise total factor

\begin{tabular}{|c|c|c|c|c|c|}
\hline & \multirow{2}{*}{$\frac{\text { Total effect }}{(1)}$} & \multicolumn{2}{|c|}{ Mediating effect } & \multicolumn{2}{|c|}{ Mediating effect } \\
\hline & & (2) & (3) & (4) & (5) \\
\hline Variables & TFP_G & DFC & TFP_G & RER & TFP_G \\
\hline \multirow[t]{2}{*}{$\mathrm{CD}$} & $1.056 * * *$ & $-0.011 * * *$ & $1.004 * * *$ & $0.179 * * *$ & $0.801 * * *$ \\
\hline & $(7.88)$ & $(-2.70)$ & $(7.56)$ & $(7.00)$ & (6.13) \\
\hline \multirow[t]{2}{*}{ DFC } & & & $-4.514 * * *$ & & \\
\hline & & & $(-6.18)$ & & \\
\hline \multirow[t]{2}{*}{ RER } & & & & & $1.423 * * *$ \\
\hline & & & & & (12.03) \\
\hline Control & Yes & Yes & Yes & Yes & Yes \\
\hline \multirow[t]{2}{*}{ Cons } & $-7.942 * * *$ & $0.051 * * *$ & $-7.710 * * *$ & 0.014 & $-7.963 * * *$ \\
\hline & $(-52.08)$ & (10.59) & $(-49.56)$ & $(0.49)$ & $(-54.24)$ \\
\hline $\operatorname{Adj} R^{2}$ & 0.880 & 0.308 & 0.882 & 0.349 & 0.889 \\
\hline Sobel_P & & \multicolumn{2}{|c|}{0.013} & \multicolumn{2}{|c|}{0.000} \\
\hline Indirect effect & & \multicolumn{2}{|c|}{$0.052 * * *$} & \multicolumn{2}{|c|}{$0.255^{* * *}$} \\
\hline Direct effect & & \multicolumn{2}{|c|}{$1.004 * * *$} & \multicolumn{2}{|c|}{$0.801 * * *$} \\
\hline \multicolumn{2}{|c|}{ Proportion of Indirect effect } & \multicolumn{2}{|c|}{$4.911 \%$} & \multicolumn{2}{|c|}{$24.151 \%$} \\
\hline
\end{tabular}

Note: ***,**** represent significant at the significance level of $1 \%, 5 \%$, and $10 \%$ respectively.The

Table 9 The regression results of non-monetary carbon disclosure quality and enterprise

\begin{tabular}{lccccc}
\multicolumn{5}{c}{ total factor productivity from the perspective of financing structure } \\
\hline & Total effect & \multicolumn{2}{c}{ Mediating effect } & \multicolumn{2}{c}{ Mediating effect } \\
\hline \multirow{2}{*}{ Variables } & $(1)$ & $(2)$ & $(3)$ & $(5)$ & $(6)$ \\
\hline NMCD & TFP_G & DFC & TFP_G & RER & TFP_G \\
\cline { 2 - 5 } & $0.593^{* * *}$ & $-0.006^{*}$ & $0.562^{* * *}$ & $0.097^{* * *}$ & $0.448^{* * *}$ \\
DFC & $(5.34)$ & $(-1.82)$ & $(5.12)$ & $(4.60)$ & $(4.18)$ \\
& & & $-4.701^{* * *}$ & & \\
RER & & $(-6.39)$ & & \\
& & & & & $1.488^{* * *}$ \\
Control & Yes & Yes & Yes & Yes & $(12.60)$ \\
Cons & $-7.885^{* * *}$ & $0.051^{* * *}$ & $-7.646^{* * *}$ & 0.024 & $-7.921^{* * *}$ \\
& $(-51.30)$ & $(10.47)$ & $(-48.84)$ & $(0.82)$ & $(-53.72)$ \\
Adj_R ${ }^{2}$ & 0.877 & 0.306 & 0.880 & 0.339 & 0.887
\end{tabular}




\begin{tabular}{lcc} 
Sobel_P & 0.079 & 0.000 \\
Indirect effect & $0.030^{* * *}$ & $0.145^{* * *}$ \\
Direct effect & $0.562 * * *$ & $0.448 * * *$ \\
Proportion of Indirect effect & $5.071 \%$ & $24.442 \%$ \\
\hline
\end{tabular}

Note: $* * * * * *$ represent significant at the significance level of $1 \%, 5 \%$, and $10 \%$ respectively.The

$T$ statistics are in parentheses.

Table 10 The regression results of monetary carbon disclosure quality and enterprise total

\begin{tabular}{|c|c|c|c|c|c|}
\hline & \multirow{2}{*}{$\frac{\text { Total effect }}{(1)}$} & \multicolumn{2}{|c|}{ Mediating effect } & \multicolumn{2}{|c|}{ Mediating effect } \\
\hline & & (2) & (3) & (5) & (6) \\
\hline \multirow{2}{*}{$\frac{\text { Variables }}{\mathrm{MCD}}$} & TFP_G & DFC & TFP_G & RER & TFP_G \\
\hline & $\begin{array}{c}0.995^{* * *} \\
(8.49)\end{array}$ & $\begin{array}{c}-0.011 * * * \\
(-2.92)\end{array}$ & $\begin{array}{c}0.947 * * * \\
(8.14)\end{array}$ & $\begin{array}{c}0.174 * * * \\
(7.76)\end{array}$ & $\begin{array}{c}0.752 * * * \\
(6.54)\end{array}$ \\
\hline DFC & & & $\begin{array}{c}-4.457^{* * *} \\
(-6.12)\end{array}$ & & \\
\hline RER & & & & & $\begin{array}{c}1.402 * * * \\
(11.83)\end{array}$ \\
\hline Control & Yes & Yes & Yes & Yes & Yes \\
\hline Cons & $\begin{array}{c}-8.009 * * * \\
(-52.47)\end{array}$ & $\begin{array}{c}0.052^{* * * *} \\
(10.71)\end{array}$ & $\begin{array}{c}-7.777 * * * \\
(-49.91)\end{array}$ & $\begin{array}{l}0.002 \\
(0.08)\end{array}$ & $\begin{array}{c}-8.013 * * * \\
(-54.47)\end{array}$ \\
\hline Adj_R $R^{2}$ & 0.880 & 0.308 & 0.883 & 0.353 & 0.889 \\
\hline Sobel_P & & & & & \\
\hline Indirect effect & & 0.0 & $* * *$ & 0.2 & $* * *$ \\
\hline Direct effect & & 0.9 & $* * *$ & 0.7 & $* * *$ \\
\hline Proportion of & idirect effect & & & 24. & $4 \%$ \\
\hline
\end{tabular}

Note: $* * * * * * *$ represent significant at the significance level of $1 \%, 5 \%$, and $10 \%$ respectively.The

$T$ statistics are in parentheses.

\section{Discussion and Conclusion}

\subsection{General Discussion}



and internal financing capabilities as mediating variables, to analyze the mechanism and transmission path of carbon disclosure quality and heterogeneous carbon disclosure quality on total factor productivity. The results show that there is a positive relationship between the quality of carbon disclosure and total factor productivity in China's heavy pollution industries, and the financing structure plays a mediating effect on the quality of carbon disclosure and total factor productivity. disclosure all play a positive effect on the improvement of corporate total factor productivity. Among them, the effect of monetary carbon disclosure quality on the improvement of total factor productivity is higher than that of non-monetary carbon disclosure quality. This shows that higher quality of carbon disclosure can reduce the information asymmetry that hinders total factor productivity (Kleimeier and Viehs, 2016), and thus promote total factor productivity. Meanwhile, the quality of non-monetary carbon disclosure is indirectly related to business performance, and there is uncertainty in expected returns ( $\mathrm{Li}$ factor productivity.

Second, the external financing costs are negatively related to total factor productivity, while there is a positive relationship between the internal financing capabilities and total factor productivity. This increases the costs of external financing (Yu and Wang, 2016), and thus inhibits the improvement of total factor productivity. However, internal financing does not involve agency cost, which has the characteristics of low cost and fast approval (He et al.,2019). Internal financing is beneficial to the 
improvement of total factor productivity.

Third, external financing costs and internal financing capabilities play a mediating effect in carbon disclosure and total factor productivity, and the mediating effect of internal financing capabilities is better than that of external financing costs. It shows that under the effect of high-quality carbon disclosure, the external financing constraints faced by enterprises can be improved ( $\mathrm{Li}$ and Foo, 2015), and the internal financing capabilities can be improved, which is beneficial to the improvement of enterprises' total factor productivity. Besides, under the effect of agency costs (Bessonova and Gonchar, 2017), the improvement of the internal financing capabilities of enterprises has a significantly higher promotion effect on total factor productivity than the positive effect of the reduction of external financing costs. Therefore, enterprises will give priority to internal financing to improve total factor productivity, which is in line with the Pecking Order Theory (Park, 2019).

Finally, external financing costs and internal financing capabilities have also a mediating effect on heterogeneous carbon disclosure and total factor productivity. The mediating effect of internal financing capabilities in heterogeneous carbon disclosure and total factor productivity is significantly higher than that of external financing costs. It shows that to obtain more innovation funds, companies need to focus on the quality of monetary carbon disclosure ( $\mathrm{Li}$ et al., 2019), with the quality of non-monetary carbon as the subsidiary, and build a systematic and comprehensive carbon disclosure quality report, which is conducive to improving corporate environmental performance (Hahn and Lülfs, 2014; Xu et al., 2015). It is beneficial to improve the total factor productivity of enterprises.

\subsection{Practical value}

The above research has certain practical value: First, the empirical results show that the effect of monetary carbon disclosure quality on total factor productivity is significantly higher than that of non- 
monetary carbon disclosure. When companies disclose carbon information, they can tend to disclose more information related to financial performance, such as low-carbon economic benefits, low-carbon scientific research results, and improve the company's total factor productivity through high-quality monetary carbon information disclosure to occupy the market competitive advantage. Second, the empirical results show that the mediating effect of internal financing capabilities is significantly better than the mediating effect of external financing costs. Although high-quality carbon disclosure reduces the negative effects of information asymmetry and agency costs, it is not as effective as increasing the strength of internal financing capabilities in reducing external financing costs. Therefore, Enterprises can adopt the mode of internal financing as the main mode and external financing as the auxiliary mode to carry out carbon disclosure, to better promote the level of enterprise total factor productivity.

\subsection{Limitations and Future Research Opportunities}

The future prospects of this research are as follows: First, this paper selects the A-share heavy pollution industry companies as the research samples and does not include low-carbon industries in the scope of the research. The impact of enterprise carbon disclosure on total factor productivity and the mediating effect of financing structure may be different among different industries. The follow-up research should further expand the research sample to low-carbon industries, and more comprehensively examine the internal mechanism between carbon disclosure and total factor productivity. Second, carbon disclosure data is collected manually according to the evaluation index system of existing research. There are some subjective factors in the measurement standard of carbon disclosure. The follow-up research should adopt Python technology to process enterprise carbon disclosure data, and measure the quality of enterprise carbon disclosure more objectively. Third, some scholars have used the adjustment path analysis method of Edwards and Lambert (2007) to test the non-linear intermediary effect. Subsequent 
research can use this method to test the intermediary effect of financing structure and analyze the nonlinear mediating effect of financing structure.

\section{Declaration}

\section{Ethics approval:}

$$
\text { Not applicable. }
$$

\section{Consent to participate:}

$$
\text { Not applicable. }
$$

\section{Consent for publication:}

$$
\text { Not applicable. }
$$

\section{Availability of data and materials:}

The datasets used and/or analysed during the current study are available from the corresponding author on reasonable request.

\section{Competing interests:}

All authors declare no competing interests

\section{Funding:}

This study is supported by the National Natural Science Foundation of China (Grant Nos. 71734001;71934001); the National Social Science Foundation Project (Grant Nos. 17BGL266); Program for Liaoning innovative talents in University (Grant Nos. WR2019003); Liaoning Provincial Economic and Social Development Project (Grant Nos. 20211slybkt-008); Fundamental Research Funds of Dalian University of Technology (Grant Nos. DUT21RW209).

\section{Authors' contributions:}




\section{References} debt. Accounting and Finance, 53, 31-53.

Al-Tuwaijri S.A., Christensen T.E., \& Hughes K.E. (2004). The relations among environmental Acc Organ Soc, 29(5-6), 447-471. international firms: Old controversies and new evidence on performance and disclosure. Academy of Management Perspectives, 30, 24-39. firms different?. Research Policy, 45(6), 1263-1274. example of the discourse on climate change. Journal of Business Ethics, 119, 287-300. costs. Economic Systems, 45(1), 26-40. 
Brown, J. R., Martinsson, G., \&Petersen B. C. (2012). Do Financing Constraints Matter for R\&D?. European Economic Review, 56(8),1512-1529.

Bui, B., Moses, O., \&Houqe, M.N. (2020). Carbon disclosure, emission intensity and cost of equity capital: multi-country evidence. Accounting and Finance, 60(1),47-71.

Chen, J. C., Cho, C. H., \&Patten, D. M. (2014). Initiating disclosure of environmental liability information: an empirical analysis of firm choice. Journal of Business Ethics, 125(4):681-692.

Chen, L. H., \&Gao, L. S. (2012). The pricing of climate risk. Journal of Financial and Economic Practice, 12(2), 115-131.

Choi, B. B., Lee, D., \&Psaros, J. (2013). An analysis of Australian company carbon emission disclosures. Pacific Accounting Review, 25(1), 58-79.

Clarkson, P. M., Li, Y., Pinnuck, M., \&Richardson, G. (2015). The valuation relevance of greenhouse gas emissions under the European Union Carbon Emissions Trading Scheme. The European Accounting Review, 24(3), 551-580.

Edwards, J.R., \&Lambert, L.S. (2007). Methods for Integrating Moderation and Mediation: A General Analytical Framework Using Moderated Path Analysis. Psychological Methods, 12, 1-22.

Gatto, M.D., Liberto, A.D., \&Petraglia, C. (2011). Measuring Productivity. Journal of Economic Surveys, 25(5), 952-1008.

Goss, A., \&Roberts, G. S. (2011). The impact of corporate social responsibility on the cost of bank loans. Journal of Banking \& Finance, 35, 1794-1810.

Gray, P., Koh, P. S., \&Tong, Y. H. (2009). Accruals quality, information risk and cost of capital: Evidence from Australia. Journal of Business Finance and Accounting, 36, 51-72.

Hall, B.H. (2002). The Financing of Research and Development. Oxford Review of Economic Policy, 18, 
Hall, B.H., \&Lerner, J. (2010). The Financing of R\&D and Innovation. Handbook of the Economics of Innovation, North-Holland, 1, 609-639.

Hammar, N., Belarbi, Y. (2021). R\&D, innovation and productivity relationships: Evidence from threshold panel model. International Journal of Innovation Studies, 5(3), 113-126.

Haney, A. B. (2017). Threat interpretation and innovation in the context of climate change: An ethical perspective. Journal of Business Ethics, 143, 261-276.

Hahn, R., \& Lülfs, R. (2014). Legitimizing negative aspects in GRI-oriented sustainability reporting: A qualitative analysis of corporate disclosure strategies. Journal of Business Ethics, 123(3), 401-420.

He, Y., Chen, C., \&Hu, Y. (2019). Managerial overconfidence, internal financing, and investment efficiency: Evidence from China. Research in International Business and Finance, 47, 501-510.

Healy, P.M., \&Palepu, K.G. (2001). Information asymmetry, corporate disclosure, and the capital markets: A review of the empirical disclosure literature. Journal of Accounting and Economics, 31, (1), 405-440. He, Y., Tang, Q. L., Wang, K.T. (2017). Carbon Performance versus financial performance. Account. Res. (2), 76-82.

Hoffmann, V. H., \&Busch, T. (2008). Corporate carbon performance indicators. Journal of Industrial Ecology, 12(4), 505-520.

Holmstrom, B. (1989). Agency costs and innovation. Journal of Economic Behavior \& Organization, 12(3), 305-327.

Kleimeier, S., Viehs, P. M. (2016). Carbon disclosure, emission levels, and the cost of debt. GSBE Res. Memo.

Larcker, D. F., \&Rusticus, T. O. (2010). On the use of instrumental variables in accounting research. 
Journal of Accounting and Economics, 49(3), 186-205.

Li, Y.H., Foo, C.T. (2015). A sociological theory of corporate finance: societal responsibility and cost of equity in China. Chinese Management Studies, 9(3):269-294.

Li, L., Liu, Q. Q., Tang, D. L. (2019). Carbon Performance, Carbon Information Disclosure Quality and

Cost of Equity Financing. Management Review, 31(01), 221-235.

Jung, J., Herbohn, K., \&Clarkson, P. (2018). Carbon Risk, Carbon Risk Awareness and the Cost of Debt

Financing. Journal of Business Ethics, 150(4),1151-1171.

Levinsohn, J., \&Amil P. (2003). Estimating Production Functions Using Inputs To Control For

Unobservables. Review of Economic Studies, 70(2), 317-341.

Li, D. Y., Huang, M., Ren, S. G., Chen X. H., \&Ning L.T. (2018). Environmental Legitimacy, Green

Innovation, and Corporate Carbon Disclosure: Evidence from CDP China 100. Journal of Business

Li G.Z., \&Liu L. (2009). Debt Financing Cost and Credit Discrimination on Private Listed Firms.

Li L., Liu Q. Q., Tang D. L., \&Xiong, J. C., (2017). Media reporting, carbon information disclosure, and the cost of equity financing: evidence from China. Environmental Science and Pollution Research, 24(10), 9447-9459.

Li, X. B. (2011). Sources of External Technology, Absorptive Capacity, and Innovation Capability in Luo, W. B., Guo, X. X., Zhong, S.H., \&Wang, J.Z. (2019). Environmental information disclosure quality, media attention and debt financing costs: Evidence from Chinese heavy polluting listed companies, 

of methods to test mediation and other intervening variable effects. Psychological Methods, 7, 83-104.

Olley, G. S. \& Pakes, A. (1996). The Dynamics of Productivity in the Telecommunications Equipment

Park, J. (2019). Financial constraints and the cash flow sensitivities of external financing: Evidence from

Korea. Research in International Business and Finance, 49, 241-250.

Pittman J. A., \&Fortin S. (2004). Auditor choice and the cost of debt capital for newly public firms.

Ren, S. G., Zheng, J. J, Liu, D. H, et al. (2019). Does emissions trading system improve firm's total factor productivity-Evidence from Chinese listed companie. China Industrial Economics, 5, 5-23. (In

Chinese).

Scherer, F.M. (2000). The Size Distribution of Profits from Innovation. The Economics and

Econometrics of Innovation, 473-494.

Schneider, T. B. (2011). Is environmental performance a determinant of bond pricing? Evidence from the

U.S. pulp and paper and chemical industries. Contemporary Accounting Research, 28(5), 1537-1561.

Schwartz, M., Peglow, F., Fritsch, M., \&Günther, J. (2012). What drives innovation output from

Sobel, M. E. (1982). Asymptotic confidence intervals for indirect effects in structural equations models.

In S. Leinhart (Ed.), Sociological methodology, 290-312.

93. 
Wen, F.H., Zhao, L.L., He, S.Y., \&Yang, G.Z., (2020). Asymmetric relationship between carbon emission trading market and stock market: Evidences from China. Energy Economics, 91, 104850. ownership structure: an analysis of Chinese listed firms. Australian Journal of Management, 40(2), 245276. based on time series perspective. Journal of Financial Risk Management, 5, 107-112 Regional development and carbon emissions in China. Energy Economics, 81, 25-36. and the moderation effect of media attention: Evidence from Chinese companies operating in highcarbon industries. Business Strategy and the Environment, 27(8), 1131-1144. 